\title{
The pasture-type approach for mountain pasture description and management
}

\author{
Giovanni Argenti, ${ }^{1}$ Giampiero Lombardi ${ }^{2}$ \\ 'Dipartimento di Scienze delle Produzioni Vegetali, del Suolo e dell'Ambiente agroforestale, \\ Università di Firenze; ${ }^{2}$ Dipartimento di Scienze Agrarie, Forestali e Alimentari, Università di \\ Torino, Italy
}

\begin{abstract}
The study of pastoral resources can take different approaches with the main goal of characterizing pasture vegetation and its potential carrying capacity. In recent times, the pasture-type approach has been developed in several Alpine areas - on a regional and on a district scale - starting from sward surveys carried out taking the approach formerly developed by the French pastoral school. The pasture-type approach may play an important role in defining the management of mountain and marginal environments where grazing pressure reduction remarkably affects the agro-ecosystems functions (production, landscape, wildlife, recreation, etc.). This approach is based on the concept of pasture type, which could be defined as a semi-natural vegetation (mainly exploited by grazing animals), rather homogeneous in terms of botanic composition and influenced by environmental factors and agro-pastoral management. This paper presents the pasture-type approach by discussing the results of two large studies carried out in two areas of the south side of the Alps (Piedmont and Veneto). In order to identify pasture types, the vegetation composition was assessed with a point quadrat method. It allowed the computation of species-
\end{abstract}

Correspondence: Dr. Giovanni Argenti, Dipartimento di Scienze delle Produzioni Vegetali del Suolo e dell'Ambiente agroforestale (DiPSA), Università degli Studi di Firenze, Piazzale delle Cascine, 18, 50144 Firenze, Italy. Tel. +39.055 .3288328 - Fax: +39.055 .332472 .

E-mail: giovanni.argenti@unifi.it

Key words: carrying capacity, grazing pressure, Landolt indicators, marginal areas, vegetation.

Acknowledgements: Research funded by Regione Piemonte (P.I. prof. Andrea Cavallero), Comunità Montana Comelico e Sappada and Regione del Veneto (P.I. prof. Giovanni Argenti).

The authors are grateful to prof. Paolo Talamucci (†) and prof. Andrea Cavallero for their involvement and encouragement to study pastureland vegetation.

Received for publication: 16 January 2012.

Accepted for publication: 18 January 2012.

() Copyright G. Argenti and G. Lombardi, 2012

Licensee PAGEPress, Italy

Italian Journal of Agronomy 2012; 7:e39

doi:10.4081/ija.2012.e39

This article is distributed under the terms of the Creative Common Attribution Noncommercial License (by-nc 3.0) which permits any noncommercial use, distribution, and reproduction in any medium, provided the original author(s) and source are credited. specific contribution, and of sward forage value and carrying capacity, after a multivariate statistical procedure for type classification and ordination. The site conditions (altitude, slope, aspect) and other environmental variables were surveyed. Moreover, to characterize the pasture types from the point of view of the ecological and management factors affecting vegetation composition, the Landolt indicators were used. The results achieved in the two areas were synthesised and organised into reference technical tools with the aim of using the pasture-type approach for pastoral planning. For each study area an identification key to recognize pasture types was drafted, and a handbook containing the technical sheets for pasture type identification, description and management was published. The approach here described enhances the knowledge on mountain pastoral resources, laying the foundations for their conservative management.

\section{Introduction}

Rangeland and grassland characterization, which is the starting point to supply livestock farmers with grazing management information, may be carried out according to several different approaches. Most methodologies start from the field determination of vegetation composition (Cantiani, 1985; Cavallero et al., 2002), sometimes combined with an assessment of its productivity (Pazzi, 1980; Pardini et al., 2001). Such approaches lead to the determination of the carrying capacity, i.e., the maximum stocking rate that will achieve a target level of animal performance, in a specified grazing system that can be applied over a defined time without deterioration of the grazing-land (Allen et al., 2011), that together with sward features (height, density, presence of weeds, presence of rare species, etc.) is used to define an appropriate management on a community scale and on a farm scale.

Unfortunately, the field survey stage for all these approaches may be time-consuming and burdensome when applied to large areas (pastoral area, district, or regional scale). Moreover, a broad application is often limited by the availability of financial means or labour. In order to overcome this kind of problems, some researchers proposed a simplification of field data gathering (Tothill et al., 1992; Argenti et al., 2006) or the use - with pastoral aims - of existing sets of botanic data, collected for other purposes (Roggero et al., 2002). Several attempts to monitor pastoral resources by remote sensing have also been carried out (Martinasso and Lombardi, 2004; Boschetti et al., 2007; Bocchi, 2009; Argenti et al., 2011), but acceptable results were achieved only by supervised classifications requiring large field surveys.

Since the early nineties, pastureland researchers have started to develop a different approach for the characterization of pastoral vegetation on a district or a regional scale based on the identification of pasture vegetation types (or briefly pasture types). Pasture types can be 
defined as herbaceous or mixed tree-shrub herbaceous communities characterized by the dominance of 1-2 (3) species and the constant presence of a variable number of common species ecologically similar one other (Cavallero et al., 2007). The types sharing similar ecologic conditions can be grouped into higher rank units called ecologic group, and they can be split in lower rank units, called facies or sub-types. The sub-types share the dominant species and a number of species among the type species, but they are different from each other at least for the specific contribution (SC) of the dominant species themselves. They are homogenous for vegetation composition and management potentiality, so they are the basic units of grazing management. They can be described by means of vegetation, ecological, productive, and soil parameters, and they are dynamically connected each other (Targetti et al., 2010).

The pasture-type approach has been developed and applied until now mainly for high hills or mountain areas where large scale grazing management has to be planned to prevent the negative ecologic effects of stocking rate reduction and very extensive exploitation on biodiversity and landscape (Anthelme et al., 2001). For instance, Fleury et al. (1988), Bornard and Dubost (1992), Jouglet (1999), and Bornard et al. (2004) described the use of this approach on different territorial scales in France. Some recent publications reported about the approach also for some alpine areas in Italy (Bassignana and Bornard, 2001; Gusmeroli, 2004; Ziliotto et al., 2004; Miori and Sottovia, 2005; Cavallero et al., 2007; Argenti et al., 2009). Most of the mentioned authors drew simple identification keys to allow the discrimination between vegetation types and synthetic technical sheets to describe them, containing the principal characteristics and appropriate management techniques for each identified type. Moreover, ecologic indicators were sometimes used to define the environmental conditions in which a given pasture vegetation type can be found. They are numerical values assigned to the species describing their behaviour with regard to determined ecologic factors. They were originally proposed by Ellenberg for the middle-European flora (1974). Afterwards, Landolt (1977) proposed indicators for the Swiss flora, followed by Zarzycky (1984) in Poland, and Borhidi (1993) in Hungary. Recently, a list covering Italian species has been arranged for the Ellenberg indicators by Pignatti et al. (2005). Besides grazing management purposes, the pasture-type characterization can be addressed to obtain information about the ecologic features of vegetal communities in order to evaluate the relationships with environment and management, since the latter is one of the main factor guiding the change in the pasture ecosystems (McIntyre and Lavorel, 2007).

In this paper, we report the results of two studies carried out by two teams of range scientists, in two large areas of Italian Alps, using the above-mentioned approach. The goals of this work are: i) to describe in detail the methodology used to identify the pasture types, supplying thus information useful for further investigations in similar contexts and for the production of the technical tools for pasture-type management; ii) to supply readers with some examples of possible comparisons among vegetation types sharing some ecological, environmental or composition features.

\section{Materials and Methods}

The vegetation analyses to identify pasture types were performed i) by Cavallero et al. (2007) on a representative sample of about 60,000 ha, distributed among mountain, subalpine and alpine vegetation belts inside Piedmont alpine fodder area (262,000 ha) (ISTAT, 2011), and ii) by Argenti et al. (2009) on the totality of the pastures occurring in the Comelico district (3300 ha). The two surveys were conducted along many years, precisely, 1998-2008 in Comelico and 1999-2007 in Piedmont.

In Piedmont the lithology is extremely complex and varied. Crystalline massifs are predominant (IPLA, 2009), but they alternate with calcareous rocks of sedimentary origin (limestones, dolomites, schists, etc.), especially in the southwest part of the region. In Comelico both shale-clay (siliceous) and calcareous-dolomite are represented (Targetti et al., 2010). More than 6000 and about 400 vegetation relevés were carried out in Piedmont and Comelico district, respectively. Though the investigated surfaces were different, the number of surveys in each area resulted in a comparable sampling intensity (Table 1), which allowed the comparison of the results.

In both studies vegetation data were collected by applying a point intercept method (Daget and Poissonet, 1969) to transects positioned inside homogeneous vegetation areas whose surface ranged from 50 $100 \mathrm{~m}^{2}$ to several hectares. In addition, the XYZ coordinates of each transect were recorded with a handheld GPS and the areas around each transects were mapped on a 1:10,000 scale. These data were uploaded into a GIS environment where the main land morphology parameters (altitude, slope, aspect) were determined.

The vegetation data were analysed by computing single species per cent contribution to vegetation composition $\left(\mathrm{SC}_{i}\right)$ of each transect, i.e., the percentage presence of a given species in the sward, as follows (Daget and Poissonet, 1969):

$$
\mathrm{SC}_{i}=\frac{\mathrm{SF}_{i}}{\sum \mathrm{SF}_{i}} * 100
$$

being $\mathrm{SF}_{\mathrm{i}}$ the specific frequency of a given species, i.e., the number of times a species is counted along the transect.

With the goal of identifying the plant communities units (types, subtypes) in both the areas under study, the matrices of surveys were classified by the Hierarchical agglomerative Cluster Analysis (HCA; Aldenderfer and Blashfield, 1984) using Pearson correlation as similarity coefficient and average linkage as agglomeration method in Piedmont, and Bray-Curtis dissimilarity coefficient (Bray and Curtis, 1957) and Ward as agglomeration method in Comelico. Each cluster partition identified a unique vegetation type at a first level, which could be split into sub-types (facies), at a lower level. The good quality of the classification was checked with a bootstrap validation procedure

Table 1. Extension, number of surveys, and sampling intensity in the two study areas.

\begin{tabular}{lccc} 
Study area & Investigated surface (ha) & Number of relevés & Survey $\left(\mathrm{ha}^{-1}\right)$ \\
Piedmont & 59,155 & 6290 & 9.40 \\
Comelico (Veneto) & 3309 & 386 & 8.57 \\
\hline
\end{tabular}


(Wishart, 1999) performed starting from the original data set. Afterwards, the pastoral value (PV; Daget and Poissonet, 1972) of each transect was computed using the following formula:

$\mathrm{PV}=0.2 \times \Sigma\left(\mathrm{SC}_{\mathrm{i}} \times \mathrm{SI}_{\mathrm{i}}\right)$

where $\mathrm{SI}_{\mathrm{i}}$ is a specific index - ranging from 0 to 5 - which summarizes the forage value of a species (Roggero et al., 2002; Cavallero et al., 2007). The pastoral value is a synthetic index (theoretically ranging from 0 to 100) of the forage potential of pasture vegetation (Cavallero et al., 2007), which can be easily converted into carrying capacity (Daget and Poissonet, 1972; Cavallero et al., 2002).

To describe the average conditions in which it is likely to find a given pasture type and to underline the ecological differences among the types, a gradient analysis based on ecological indexes (Whittaker, 1967) was performed. For each of the eight environmental factors reported in Table 2, Landolt indicators (1977) were used so that each species in a survey was assigned a value ranging from 1 to 5 - depending on the intenseness - for that given species. The mean indicator values of each survey were computed subsequently by averaging the species values weighted on their abundance $\left(\mathrm{SC}_{\mathrm{i}}\right)$. Such values were used to perform a principal component analysis (PCA; Swaine and Greig-Smith, 1980) to define the ecological space occupied by a pasture type, as performed in previous studies on vegetation (Whittaker, 1967; Persson, 1981; Lonati, 2005). Then, all the identified types were characterised by the mean values of the Landolt indicators by averaging the values of the surveys ascribable to that type. In order to represent the pasture type ecologic features, radar diagrams were drawn.

Finally, vegetation, ecology, and land-morphology data were used to draw, for each study area, i) practical tools for the on-field identification of the pasture types (dichotomous key), and ii) technical sheets containing the description of type features and the guidelines for the grazing management and the exploitation of the type itself. Each sheet was divided into two parts: the first containing the main ecological and vegetation descriptors (also to confirm the recognition of the type made on the ground); the second containing the key information for the pastoral exploitation (PV, productivity, carrying capacity, etc.) and the guidelines for optimum management. Suggested guidelines were drawn according to good agricultural practices criteria with the aim of preserving vegetation and landscape diversity, of the grassland forage quality, and, whenever possible, of the improvement of the quality of animal productions.

\section{Results and discussion}

Six vegetation types and 16 sub-types were identified through the classification processes in Comelico district (Table 3). Ninety-two types were identified in Piedmont (652 sub-types), seven of which occurring on $70 \%$ of the sampled area and 85 scattered on the remaining portion, i.e., with a small mean surface, although sometimes locally extended over large areas. Even operating on study areas very different in terms of surface, the pasture vegetation of both the analysed situations was effectively described, and the different number of types identified could be mainly due to different extension of the areas. Though the remarkable distance between the two areas, the dominant vegetation was similar: matgrass (Nardus stricta) type covered large surfaces in Comelico and Piedmont. This type is a typical oligotrophic low-forage value type (average PV 16) resulting mainly from the transfer of animal manure from remote areas grazed by cattle, that become poorer and poorer in nutrients, to the night camps or sheds that are generally far from grazed areas.

In Comelico, the extension of blueberry (Vaccinium myrtillus) type over one third of the whole area indicated that the capability of the grassland ecosystem to provide its services (forage production, biodiversity, recreation, etc.) was almost completely compromised. In Piedmont, the same situation was evidenced by the extension of Brachypodium rupestre type (7\% of the studied area), a thermic condi-

Table 2. Landolt indicators used in the studies.

\begin{tabular}{ll} 
Index & Description \\
$\mathrm{U}$ & soil Humidity \\
$\mathrm{R}$ & soil Reaction (pH) \\
$\mathrm{N}$ & Nutrients (especially N) in the soil \\
$\mathrm{H}$ & Humus content \\
\hline $\mathrm{D}$ & Dispersion (aeration) of the soil \\
$\mathrm{L}$ & Light needs \\
$\mathrm{T}$ & Temperature needs \\
$\mathrm{C}$ & Continentality \\
\hline
\end{tabular}

Table 3. Pasture types ranked by surface.

\begin{tabular}{|c|c|c|c|c|c|c|}
\hline Pasture type & es (number) & Relevés (number) & Surface (ha) & Altitude (m asl) & Slope $(\%)$ & PV \\
\hline \multicolumn{7}{|l|}{ Comelico district } \\
\hline Nardus stricta & 3 & 109 & 1176 & 2129 & 21 & 17 \\
\hline Vaccinium myrtillus & 3 & 74 & 966 & 2035 & 42 & 8 \\
\hline Festuca gr. rubra & 3 & 80 & 407 & 1910 & 18 & 19 \\
\hline Carex curvula & 2 & 25 & 351 & 2251 & 21 & 12 \\
\hline Deschampsia caespitosa & 3 & 61 & 215 & 1856 & 19 & 32 \\
\hline Sesleria varia & 2 & 37 & 194 & 1948 & 36 & 15 \\
\hline \multicolumn{7}{|l|}{ Piedmont mountains } \\
\hline Nardus stricta & 58 & 561 & 9836 & 2000 & 19 & 15 \\
\hline Festuca paniculata & 28 & 223 & 9052 & 2068 & 26 & 17 \\
\hline Festuca gr. rubra and Agrostis tenuis & 40 & 563 & 7194 & 1705 & 19 & 30 \\
\hline Festuca scabriculmis & 18 & 93 & 4701 & 2076 & 32 & 8 \\
\hline Brachypodium rupestre & 38 & 231 & 4054 & 1642 & 25 & 19 \\
\hline Trifolium alpinum and Carex sempervirens & 24 & 271 & 3234 & 2300 & 19 & 21 \\
\hline Festuca gr. ovina & 28 & 222 & 2778 & 2000 & 23 & 21 \\
\hline Other types & 418 & 4126 & 18,306 & - & - & - \\
\hline
\end{tabular}

$\mathrm{PV}$, pastoral value. 
tion type which could not be found in Comelico because of different altitude and precipitation regime, and of some sub-types of Festuca paniculata type. Low mean forage values (PV 15 and 19 in Comelico and Piedmont, respectively) evidenced that general impoverishment of vegetation is a phenomenon diffused in the eastern as well as in the western Italian Alps due to past and current not-rational grazing management. In both the areas, the type with dominance of red fescue (Festuca gr. rubra) was ranked first among the pasture types of medium-good forage quality (PV 30 in Piedmont and PV 19 in Comelico). As matgrass and blueberry types are often the evolution of red fescue grasslands, it probably occurred on larger surfaces in the past. Moreover, in Comelico other forms of vegetation degradation affected a large portion even of the good forage quality areas, where red fescue was abundant. The tussock grass (Deschampsia caespitosa) type was identified because of the dominance of tussock grass (resulting probably from biogeographic and environmental factors), but it shared the majority of its composition with Festuca gr. rubra type. As already mentioned, thermic condition types (Festuca scabriculmis, Brachypodium rupestre, Festuca gr. ovina) occurred only in Piedmont. On the steep slopes of Comelico, the type dominated by vicariant Sesleria varia on calcareous soils replaced Festuca scabriculmis type, established in Piedmont on acid soils. Further information about the ecologic features of the identified types were obtained by comparing the Landolt indicators computed for the two areas. The two matgrass types were comparable for all the indicators except for soil dispersion (aeration) and continentality (Figure 1). As expected, Nardus stricta grasslands of western Alps grew under more continental climate than the ones of eastern Alps, where a large amount of precipitation occurs even during growing season. The differences for red fescue types (Figure 2) concerned again continentally and soil dispersion, but also: i) temperature, whose value was higher in Piedmont, where red fescue grasslands spread also on moderate slopes (about $50 \%$ of the surveys); ii) soil reaction, being Comelico soils with red fescue cover more acid, while Piedmont mean
$\mathrm{pH}$ values were higher; iii) nutrient value, whose values were lower in Comelico, as shown by the lower pastoral values to which nutrient value is generally well correlated (Parolo et al., 2011). Concerning the types occurring exclusively in one of the two areas, e.g. Festuca scabriculmis that occurred only in Piedmont (Figure 3), Landolt indica-

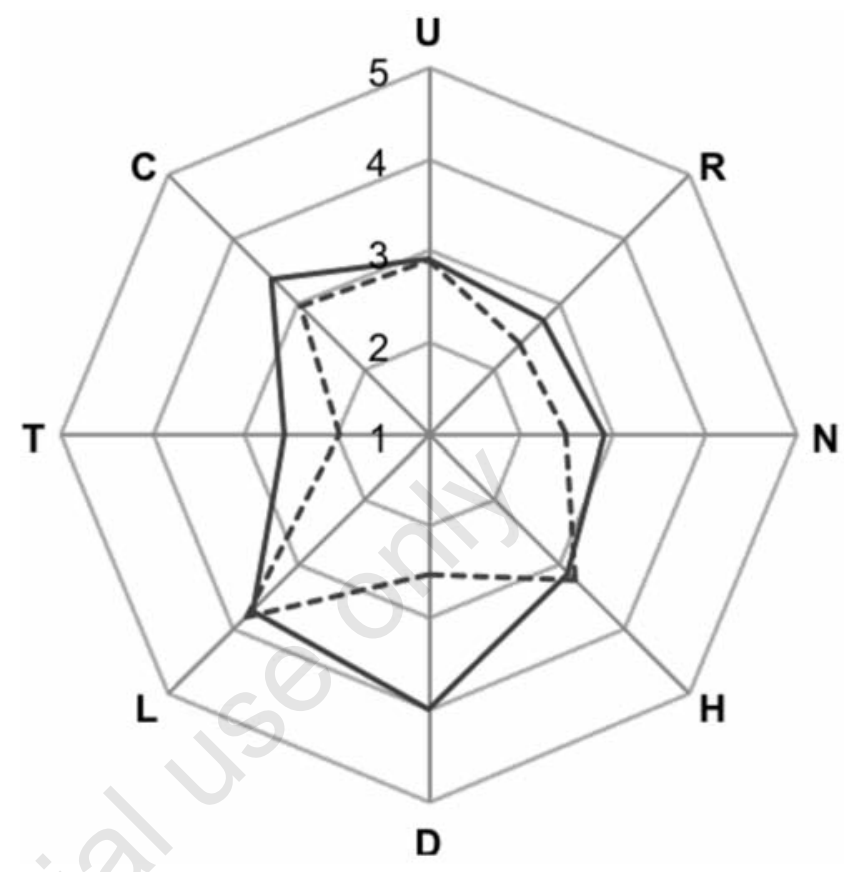

Figure 2. Radar chart of mean Landolt indicators for Festuca gr. rubra type (Piedmont: continuous line; Comelico: dashed line).

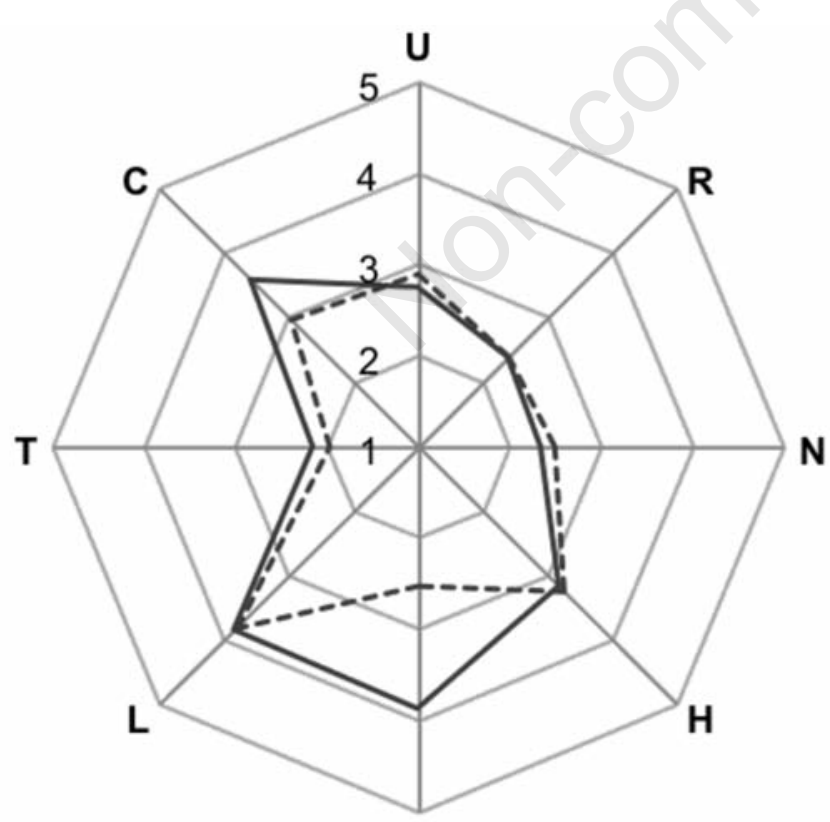

D

Figure 1. Radar chart of mean Landolt indicators for Nardus stricta type (Piedmont: continuous line; Comelico: dashed line).

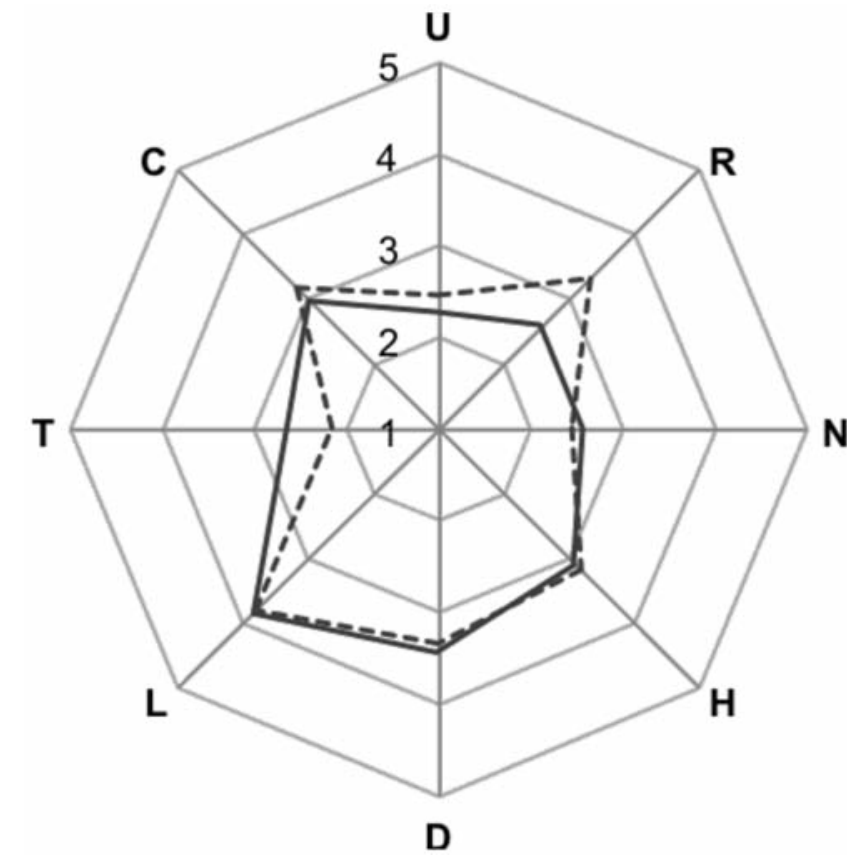

Figure 3. Radar chart of mean Landolt indicators for Festuca scabriculmis type in Piedmont (continuous line) and Sesleria varia type in Comelico (dashed line). 
tors could effectively evidence which ecologic factor the presence of the type depended on, and the differences with types sharing most of the ecologic conditions in the other area (e.g. Sesleria varia that grows in the same conditions with the exception of soil reaction which was neutral-alkaline instead of acid).

The comparison of vegetation and ecological pasture types descriptors allowed the identification of the parameters useful to describe the environmental characteristics that affect the diffusion of a given type. As one of the principal goals of the two studies in Piedmont and Comelico district was to supply low-moderately specialised operators with tools they could use for the type recognition, the vegetation, ecology, and physiognomy parameters were collected, together with management recommendation and distribution maps, into technical sheets drafted for each type. A list of the basic descriptors resulting from the match of the two series of technical sheets (Cavallero et al., 2007; Argenti et al., 2009) is reported in Table 4.

The operators should look at the technical sheets at the end of a field recognition process during which dichotomous keys based on some easy-to-identify parameters (physiognomy, groups of species, topographic features, management evidences, soil characteristics, etc.) are

Table 4. Pasture type descriptors for handbook or technical sheet drafting (from Cavallero et al., 2007, and Argenti et al., 2009).

\begin{tabular}{|c|c|c|}
\hline Category & Descriptor & Tool \\
\hline Physiognomy & $\begin{array}{l}\text { - Description of the sward features evident at first sight: height, density, percentage } \\
\text { of bare soil/vegetation cover, presence of senescent phytomass, } \\
\text { dominant species habitus (tuft size and density, leaf size, etc.) }\end{array}$ & Technical sheet, pictures, plant drawings \\
\hline Distribution & - Distribution of the type in the area of application & Map \\
\hline Ecology & $\begin{array}{l}\text { - Site conditions: altitude, slope, aspect } \\
\text { - Synecology (description of ecologic conditions): Landolt indicators } \\
\text { mean Landolt indicators, ordination plots }\end{array}$ & $\begin{array}{l}\text { Charts with means and variability measures } \\
\text { Technical sheet, radar charts to represent }\end{array}$ \\
\hline Vegetation & $\begin{array}{l}\text { - Composition: dominant species, frequent species, locally abundant species } \\
\text { - Phytosociology: alliance, association (Grabherr and Mucina, 1993; Mucina et al., 1993a; } \\
\text { Mucina et al., 1993b) } \\
\text { - Sub-type list (sub-types sorted according to gradients) } \\
\text { - Sub-type composition (SCi) } \\
\text { - Habitat Directive (92/43/EEC) code, if any } \\
\text { - Presence of threatened species from IUCN Red List (IUCN, 2011) } \\
\text { and Italian Red List (Conti et al., 1997) }\end{array}$ & $\begin{array}{l}\text { Tables } \\
\text { Tables, list } \\
\text { Tables } \\
\text { Tables } \\
\text { Tables } \\
\text { List }\end{array}$ \\
\hline $\begin{array}{l}\text { Pastoral and } \\
\text { environmental values }\end{array}$ & $\begin{array}{l}\text { - Pastoral value (PV, Daget and Poissonet, 1972): } \\
\text { overall average value and values by sub-type } \\
\text { - Landscape value }\end{array}$ & $\begin{array}{l}\text { Tables, charts with means and variability } \\
\text { measures }(e . g \text {. boxplot) } \\
\text { Tables }\end{array}$ \\
\hline Management & $\begin{array}{l}\text { - Management goals: conservation, improvement, restoration, abandonment } \\
\text { (no management) } \\
\text { - Species and classes of exploiting animals } \\
\text { - Carrying capacity } \\
\text { - Stocking-rate: maximum and recommended } \\
\text { - Recommended exploitation: stocking method, optimal moment, } \\
\text { number of grazing events } \\
\text { - Dung management } \\
\text { - Possible vegetation evolution in relation to management }\end{array}$ & $\begin{array}{l}\text { Technical sheet } \\
\text { Tables } \\
\text { Tables } \\
\text { Tables } \\
\text { Technical sheet } \\
\text { Technical sheet } \\
\text { Tables, block diagram }\end{array}$ \\
\hline
\end{tabular}

Table 5. Example of dichotomous key for pasture type identification in Comelico district (from Argenti et al., 2009).

\begin{tabular}{|c|c|c|}
\hline Step & Identification key & $\begin{array}{l}\text { Pasture type/ } \\
\text { next step }\end{array}$ \\
\hline 1 & $\begin{array}{l}\text { Pasture dominated by heathland shrubs (i. e. Vaccinium myrtillus, Calluna vulgaris, Rhododendron ferrugineum) } \\
\text { Pasture without or with reduced presence of shrubs }\end{array}$ & $\begin{array}{l}\text { V. myrtillus } \\
2\end{array}$ \\
\hline 2 & $\begin{array}{l}\text { Pasture located above } 2000 \mathrm{~m} \text { asl } \\
\text { Pasture located below } 2000 \mathrm{~m} \text { asl }\end{array}$ & $\begin{array}{l}3 \\
4\end{array}$ \\
\hline 3 & $\begin{array}{l}\text { High presence of Carex curvula and lichens } \\
\text { Pasture not dominated by Carex curvula }\end{array}$ & $\begin{array}{l}\text { C. curvula } \\
5\end{array}$ \\
\hline 4 & $\begin{array}{l}\text { Pasture mainly flat and in the surroundings of animal shelters, with high presence of Deschampsia caespitosa, } \\
\text { Alchemilla vulgaris, Festuca gr. rubra and Phleum alpinum } \\
\text { Pasture dominated by other species }\end{array}$ & $\begin{array}{l}\text { D. caespitosa } \\
5\end{array}$ \\
\hline 5 & $\begin{array}{l}\text { Pasture on calcareous soil } \\
\text { Pasture on acid soil }\end{array}$ & $\begin{array}{l}6 \\
7\end{array}$ \\
\hline 6 & $\begin{array}{l}\text { Pasture dominated by Sesleria varia and Carex sempervirens } \\
\text { Pasture dominated by Festuca gr. rubra }\end{array}$ & $\begin{array}{l}\text { S. varia } \\
\text { F. gr. rubra }\end{array}$ \\
\hline 7 & $\begin{array}{l}\text { Pasture dominated by Nardus stricta } \\
\text { Pasture dominated by Festuca gr. rubra }\end{array}$ & $\begin{array}{l}\text { N. stricta } \\
\text { F. gr. rubra }\end{array}$ \\
\hline
\end{tabular}


used. An example of such keys is reported for Comelico district in Table 5 , in which vegetation and physical parameters were used to identify the typical ecological conditions of a given type. In the proposed example, the proper identification of a pasture type depended on little knowledge of a limited number of dominant or indicator species. The proposed key could be applied only locally or in comparable conditions, while its use should be discouraged in different areas without adjustments. In some circumstances (Cavallero et al., 2007) this tool could be used to accomplish the identification of a given pastoral sub-type, but in this occurrence the identification by the key should follow a vegetation survey to accurately describe sward composition.

\section{Conclusions}

The pasture-type approach as proposed by Cavallero et al. (2007) and Argenti et al. (2009) and summarized in this paper, demonstrated to be useful to pasture vegetation assessment and proposition of an appropriate management of pastoral resources. This common approach allowed the analysis of areas with different surfaces for which the main pasture types occurring in each region were identified and a proper management scheme for each type was proposed. Moreover, such an approach allowed also the type ecological descriptions by means of simple and already existing indicators. The use of Landolt indicators permitted to identify which parameter is more related to a given type, enhancing the possibility of pasture-type recognition on the terrain, and to compare similar types in the two regions and different types in ecologic condition similar but for one or more factors.

The arrangement of data in a handbook containing technical sheets with the type descriptions from the point of view of vegetation and management, and keys for type identification is a condition for an efficient implementation of such an approach suggested also for other pasture-type studies. The handbook could be used as a quick-guide for an appropriate management of wide area, just with the identification of occurring pasture types. Actually, tools like these offer a range of opportunities coming from the pastoral type identification, classification and concerning characteristics, and they allow the assessment of the most appropriate management under vegetation successions in action. The pasture types become a technical instrument for agro-environmental management as they involve an agricultural production system related to a fragile environment and a typical landscape (Petit et al., 2004). In fact, in Piedmont the pasture-type approach according to Cavallero et al. (2007) has already been used to draft the pastoral plans for mountain summer pastures within the framework of the agro-environmental measures of Rural Development Plan 2007-2013.

The conservation of the fragile environments and landscapes of the Alps and the drawing of biodiversity action plans would take advantage from the large database resulting from the two researches, especially when endangered vegetation communities, rare biotopes or site of Community importance are concerned.

\section{References}

Aldenderfer MS, Blashfield, RK, 1984. Cluster analysis. Sage University Paper series 7-44. Sage Publ., Beverley Hills, CA, USA.

Allen VG, Batello C, Berretta EJ, Hodgson J, Kothmann M, Li X, Mclvor J, Milne J, Morris C, Peeters A, Sanderson M, 2011. An international terminology for grazing lands and grazing animals. Grass Forage Sci. 66:2-28.

Anthelme F, Grossi JL, Brun JJ, Didier L, 2001. Consequences of green alder expansion on vegetation changes and arthropod communi- ties removal in the northern French alps. Forest Ecol. Manag. 145:57-65.

Argenti G, Bianchetto E, Ferretti F, Staglianò N, 2006. Proposta di un metodo semplificato di rilevamento pastorale nei piani di gestione forestale. Forest@3:275-80.

Argenti G, Bottai L, Chiesi M, Maselli F, Staglianò N, Targetti S, 2011. Analisi e valutazione di pascoli montani attraverso l'integrazione di dati multispettrali e ausiliari. Ital. J. Remote Sens/Riv. Ital. Telerilevam. 43:45-57.

Argenti G, Staglianò N, Targetti S, 2009. I pascoli del Comelico. Guida alla conoscenza delle risorse pastorali. Grafica Znoymo, Pontassieve, Italy.

Bassignana M, Bornard A, 2001. Tipologia agroecologica delle vegetazioni d'alpeggio in zona intra-alpina nelle Alpi Nord-occidentali. Cemagref-IAR, Aosta, Italy.

Bocchi S, 2009. Applicazione integrata di tecniche GIS, remote sensing e indagine agro-ecologica per la caratterizzazione delle risorse foraggere e la produzione di cartografia tematica. In: M. Soster and P. Aceto (eds.) La gestione sostenibile dei sistemi pascolivi italiani. Descrizione generale. Progetto Maso-GIS. Regione Piemonte, Direzione Agricoltura, Settore Servizi di sviluppo agricolo. Quaderni della Regione Piemonte-Agricoltura, n.61 (suppl.), Torino, Italy, pp 55-67.

Borhidi A, 1993. Social behaviour types of the Hungarian flora, its naturalness and relative ecological indicator values. Janus Pannonius Tudom. Kiadv., Pecs, Hungary.

Bornard A, Bernard-Brunet C, Labonne S, Cozic P, 2004. Fiches techniques des types agro-écologique de végétation des alpages du massif de la Vanoise. Ministère de l'Écologie et du Développement Durable. Cemagref, Grenoble, France.

Bornard A, Dubost M, 1992. Diagnostic agroècologique de la végétation des alpages laitiers des alpes du Nord humides: établissement et utilisation d'une typologie simplifiée. Agronomie 12:581-99.

Boschetti M, Bocchi S, Brivio PA, 2007. Assessment of pasture production in the Italian Alps using spectrometric and satellite remote sensing information. Agr. Ecosyst. Environ. 118:267-72.

Bray JR, Curtis JT, 1957. An ordination of upland forest communities of southern Wisconsin. Ecol. Monog. 27:325-49.

Cantiani MG, 1985. L'analisi fitoecologica in alpicoltura. Ital. Forest. Mont. 40:35-52.

Cavallero A, Aceto P, Gorlier A, Lombadi G, Lonati M, Martinasso B, Tagliatori C, 2007. I tipi pastorali delle Alpi piemontesi. Alberto Perdisa Editore, Bologna, Italy.

Cavallero A, Rivoira G, Talamucci P, 2002. Pascoli. In: R. Baldoni and L. Giardini (eds.) Coltivazioni erbacee. Foraggere e tappeti erbosi. Patron Editore, Bologna, Italy, pp 239-94.

Conti F, Manzi A, Pedrotti F, 1997. Liste rosse regionali delle piante d'Italia. Dipartimento di Botanica ed Ecologia, Università di Camerino, Camerino, Italy.

Daget P, Poissonet J, 1969. Analyse phytologique des prairies. CNRSCepe, document n.50, Montpellier, France.

Daget P, Poissonet J, 1972. Un procède d'estimation de la valeur pastorale des pâturages. Fourrages 49:31-40.

Ellenberg H, 1974. Zeigerwerte der Gefäßpflanzen Mitteleuropas. Scripta Geobotanica IX. 97 S., Verlag Erich Goltze KG, Göttingen, Germany.

Fleury P, Jeannin B, Dorioz JM, 1988. Typologies des prairies de fauche de montagne des Alpes du Nord humides. INRA, SUACI Montagne, Chambéry, France.

Grabherr G, Mucina L, 1993. Die Pflanzengesellschaften Österreichs 2, Natürliche waldfreie Vegetation. G. Fischer, Jena, Germany.

Gusmeroli F, 2004. I pascoli dell'Alta Valtellina. Tipolitografia Bettini, Sondrio, Italy.

IPLA, 2009. Atlante dei suoli del Piemonte. Quattro Serie di Atlanti e 
Note illustrative. Servizi Grafici, Bricherasio (T0), Italy.

ISTAT, 2011. Banche dati, tema Agricoltura, anno 2007. Available at: http://dati.istat.it/.

IUCN, 2011. IUCN Red List of Threatened Species. Version 2011.2. Accessed on:10th November 2011. Available from: http://www.iucnredlist.org

Jouglet JP, 1999. Les végétations des alpages des Alpes françaises du Sud. Guide technique pour la reconnaissance et la gestion des milieux pâtures d'altitude. Cemagref et Aten, France.

Landolt E, 1977. Ökologische Zeigerwerte zur Schweizer Flora. Veröffentlichungen des Geobotan. Institut. der Eidig. Techn. Hochschule, Stiftung Rübel, Zürich, Switzerland.

Lonati M, 2005. Analisi di gradienti ecologici in formazioni pascolive mediante gli indici di Landolt: un esempio in Valle Maira. Ital. Forest. Mont. 5:629-40.

Martinasso B, Lombardi G, 2004. Remote sensing in NW Italian Alps for pastoral inventory and improvement of grassland management. Grassland Sci. Eur. 9:317-9.

McIntyre S, Lavorel S, 2007. A conceptual model of land use effects on the structure and function of herbaceous vegetation. Agr. Ecosyst. Environ. 119:11-21.

Miori M, Sottovia L, 2005. Prati e pascoli del Trentino. Provincia Autonoma di Trento, Assessorato all'Agricoltura al Commercio e Turismo, Trento, Italy.

Mucina L, Grabherr G, Ellmauer T, 1993a. Die Pflanzengesellschaften Österreichs 1, Anthropogene Vegetation. G. Fischer, Jena, Germany.

Mucina L, Grabherr G, Wallnöfer S, 1993b. Die Pflanzengesellschaften Österreichs 3, Wälder und Gebüsche. G. Fischer, Jena, Germany.

Pardini A, Longhi F, Lombardi P, Argenti G, 2001. Animal stocking rate in tropical and subtropical rangelands II. Comparison of methods for the calculation. J. Agric. Environ. Internat. Develop. 94:257-74.

Parolo G, Abeli T, Gusmeroli F, Rossi G, 2011. Large-scale heterogeneous cattle grazing affects plant diversity and forage value of Alpine species-rich Nardus pastures. Grass Forage Sci. 66:541-50.
Pazzi G, 1980. Dimensionamento del carico dei pascoli. L'Italia agricola 117:283-91.

Persson S, 1981. Ecological indicator values as an aid in the interpretation of ordination diagrams. J. Ecol. 69:71-84.

Petit S, Vansteelant JY, Plaige V, Fleury P, 2004. Les typologies de prairies: d'un outil agronomique à un objet de médiation entre agriculture et environnement. Fourrages 179:369-82.

Pignatti S, Menegoni P, Pietrosanti S, 2005. Bioindicazione attraverso le piante vascolari. Valori di indicazione secondo Ellenberg per le piante della flora d'Italia. Braun Blanquetia 39:1-97.

Roggero PP, Bagella S, Farina R, 2002. Un archivio di dati di indici specifici per la valutazione integrata del valore pastorale. Riv. Agron. 36:149-56.

Swaine MD, Greig-Smith P, 1980. An application of principal components analysis to vegetation change in permanent plots. J. Ecol. $68: 33-41$

Targetti S, Staglianò N, Messeri A, Argenti G, 2010. A state-and-transition approach to alpine grasslands under abandonment. iForest $3: 44-51$.

Tothill JC, Hargreaves JNG, Jones RM, Mc Donald CK, 1992. BOTANALA comprehensive sampling and computing procedure for estimating yield and botanical composition. 1. Field sampling. Tropical Agronomy Technical Memorandum, No. 78. Division of Tropical Crops and Pastures, CSIRO, Brisbane, Australia.

Wishart D, 1999. Clustan graphics primer: a guide to cluster analysis. Clustan Limited, Edinburgh, Scotland, UK.

Whittaker RH, 1967. Gradient analysis of vegetation. Biol. Rev. 42:20764.

Zarzycky K, 1984. Indicator values of vascular plants in Poland. Krakow Institut Bot., Polska Akad., Krakow, Poland.

Ziliotto U (coordinator), Andrich 0, Lasen C, Ramanzin M, 2004. Tratti essenziali della tipologia veneta dei pascoli di monte e dintorni. Regione Veneto, Accademia Italiana di Scienze Forestali, Venezia, Italy. 